\title{
Effects of Brick and Aerated Concrete Infill Walls on Buildings
}

\author{
Hacer Bilir Ozhan \\ Department of Civil Engineering, \\ Bursa Technical University, \\ Bursa, Turkey \\ hacer.ozhan@btu.edu.tr
}

\author{
Caner Beklen \\ Department of Civil Engineering, \\ Cukurova University, \\ Adana, Turkey \\ cnr_beklen@hotmail.com
}

\author{
Ismail H. Cagatay \\ Department of Civil Engineering, \\ Cukurova University, \\ Adana, Turkey \\ hcagatay@cu.edu.tr
}

\begin{abstract}
It has already been proved that infill walls have great impact on the behavior of the frame systems, especially under earthquake-like lateral loads. Infill walls are generally considered as partition members between spaces in concrete frame systems. They are generally included into calculations as dead loads exerted on beams, but they have various impacts on the behavior of frame-wall systems. Therefore, the well-known behavior of infill walls will have positive contributions. In the present study, a 10-story building was modeled with brick and aerated concrete infill walls. Window and door spaces were taken into consideration. Infill walls were modeled with the equivalent compression strut method. Changes in building rigidity, period, lateral displacement, base shear force and building behavior were investigated with relevant analyses.
\end{abstract}

Keywords-infill wall; earthquake analysis; brick; aerated concrete; equivalent compression strut

\section{INTRODUCTION}

Along with increasing sheltering demands, construction industry is continuously growing. However, the available land for construction is not increasing at the same pace, thus highrise buildings have opted. In this sense, economy and utilization of concrete frame systems have become significant issues of construction industry. Generally, light-weight materials are preferred in such frame systems especially for heat, noise and similar insulations and partition walls are constructed also with these materials to facilitate the utility of building space. Infill walls have significant effects on the bearing-system of the building under lateral loads, therefore, the behavior of these walls under lateral loads, like earthquake loads, should be well elucidated. Negative impacts of such walls are generally attributed to the diverse range of materials, the diversity in their strength, and insufficient inspections of present implementations. In practice, these walls are reflected in calculations as the members increasing only the dead loads of the building and their load-bearing behaviors are generally neglected. Observations and investigations on earthquake damages of the buildings revealed that although infill walls were not considered in calculations made for earthquakes, they resisted to lateral earthquake loads like a shear wall until time of failure. Post-failure behavior of these walls cannot be estimated accurately and they are considered as if they did not exist in calculations. Then, great damages are experienced in practice. The literature on infill walls revealed that infill walls had significant contributions to rigidity, load-bearing capacity, period and damping-like dynamic attributes of the buildings. The structure altogether behaves like a composite material. Therefore, the behavior of each and every single member of the structure should be known. In the present study, a ten-story building was modeled to investigate how effective the infill walls in increasing building resistance to vertical and especially to lateral loads. Bricks and aerated concrete were used in building infill walls. In calculations, the behavior and effects of infill walls with two different materials were investigated.

\section{MEthodOlOGY}

\section{A. Infill Walls}

There are several studies about the behavior of frame systems with/without partition walls under earthquake and similar lateral loads. In [1], experiments were conducted to determine the behavior of infill walls under lateral loads and it was reported that the concrete frame with infill walls had greater load-bearing capacity than the frames without infill walls and infill walls significantly improved building elasticity and rigidity behavior. Infill walls are not always formed in fully-filled fashion. There may be empty spaces on them left for different purposes. In cases where the infill wall was created as macro-void, the frame system with infill wall provided at least $40 \%$ greater contribution to lateral loadbearing capacity as compared to frame system without an infill wall [2]. Similarly, a soft-story concrete building and a concrete building without infill walls exhibited similar behavior with regard to lateral load bearing capacity [3]. In Turkey, ground floors are generally used for purposes other than housing. Ground floor projects are thus generally altered (columns are cut, existing walls are removed etc.). Therefore, partition walls generally do not exist in ground floors. In this case, the upper floors behave more rigid because of the partition walls in comparison with ground floors. Such a case results in concentrated energy consumption on the ground floors. A soft-story is formed in such buildings and destructive damages and failures are experienced in this weaker floor of the building. In other cases, damages are generated over the columns of these floors without infill walls. Since the earthquake energy is confronted in this floor, the rigidity of the

Corresponding author: Hacer Bilir Ozhan 
columns and shear walls of this floor should be improved as to bear inter-floor displacements. If the walls are constructed short and connected to frames, then the columns of the main frame cannot bend in between two stories they connect under lateral forces of an earthquake because of the rigidity of the walls along their own planes. Then a soft-story is formed. In this case, columns are forced to bend over the section with the empty height left over the upper sections of the walls. Then quite greater shear forces are generated over this section of the columns [4]. Long windows extending along the both sides of the walls preferred in factory-like buildings generate a shortcolumn effect and reduce the effective length of the column. Experimental works on frames with infill walls revealed that door and window spaces should be avoided on these members and thus building rigidity should be increased to reduce potential damages [5, 6] Confinement of stirrup should be increased to bear resultant shear force.

\section{B. Brick as Infill Wall Material}

Brick is one of the most commonly used and preferred materials for infill walls of concrete structures. Since the use of two different materials in infill walls is compared in this study, horizontally perforated bricks with greater hallow ratios were used since they have low compression strength. Specifications for horizontally perforated bricks are provided in Table I. While modeling infill walls, 13.5 horizontally perforated bricks were used in exterior walls and 8.5 horizontally perforated bricks were used in interior walls. G2-class aerated concrete was also used as infill wall material. This material is generally used as exterior and interior infill wall material of concrete frame structures or used as load-bearing exterior and interior wall material of masonry structures. They are composed of 70$80 \%$ less concrete, and are resistant to earthquake and fires. Specifications for G2-class aerated concrete are provided in Table II.

TABLE I. HORIZONTALLY PERFORATED BRICKS SPECIFICATIONS

\begin{tabular}{|c|c|c|}
\hline Specification & $\begin{array}{c}8.5 \text { horizontally } \\
\text { perforated bricks }\end{array}$ & $\begin{array}{c}13.5 \text { horizontally } \\
\text { perforated bricks }\end{array}$ \\
\hline Height $\times$ width $\times$ length $(\mathrm{cm})$ & $8.5 \times 19 \times 19$ & $13.5 \times 19 \times 19$ \\
\hline Mean compressive strength (MPa) & 4 & 5.2 \\
\hline Single brick weight (kg) & 2 & 3 \\
\hline Bricks per $\mathbf{m}^{2}$ & 25 & 25 or 33 \\
\hline
\end{tabular}

TABLE II. AERATED CONCRETE SPECIFICATIONS

\begin{tabular}{|c|c|c|}
\hline Specification & $\begin{array}{c}\text { For interior } \\
\text { walls }\end{array}$ & $\begin{array}{c}\text { For exterior } \\
\text { walls }\end{array}$ \\
\hline Length $\times$ height $\times$ width $(\mathbf{c m})$ & $60 \times 25 \times 8.5$ & $60 \times 25 \times 19$ \\
\hline Mean compressive strength $(\mathbf{M P a})$ & 2.5 & 2.5 \\
\hline Weight of single aerated concrete $\mathbf{( k g )}$ & 5.1 & 12 \\
\hline Number of aerated concrete per $\mathbf{~ m}^{\mathbf{2}}$ & 6.66 & 6.66 \\
\hline
\end{tabular}

\section{Modulus of Elasticity}

Infill wall modulus of elasticity significantly influences wall rigidity of frame-wall systems. Infill walls exhibit complex behavior since the modulus of elasticity values in different directions (horizontal, vertical, diagonal) are different. Significant effects of compressive strength of the material, height, compressive strength of mortar layer on the modulus of elasticity are indicated in [7]. It was also indicated that the modulus of elasticity of infill walls was different for plastered and unplastered walls and varied with the thickness of the plaster layer. Modulus of elasticity values of brick walls used in different studies are provided in Table III. In this table, $\mathrm{E}_{\mathrm{w}}$ and $E_{c}$ respectively express the modulus of elasticity of the wall and the concrete under compression.

TABLE III. BRICK WALL MODULUS OF ELASTICITY VALUES

\begin{tabular}{|c|c|c|c|}
\hline Reference & $\left.\mathbf{E}_{\mathbf{w}} \mathbf{( M P a}\right)$ & $\mathbf{E}_{\mathbf{c}}(\mathbf{M P a})$ & $\mathbf{E}_{\mathbf{d}} / \mathbf{E}_{\mathbf{c}}$ \\
\hline$[\mathbf{8}]$ & 5200 & 30000 & $1 / 6$ \\
\hline$[\mathbf{9}]$ & 1240 & 30000 & $1 / 24$ \\
\hline$[\mathbf{1 0}]$ & 2850 & 28500 & $1 / 10$ \\
\hline$[\mathbf{1 1}]$ & 6000 & 12000 & $1 / 2$ \\
\hline$[\mathbf{1 2}]$ & 700 & 25310 & $1 / 36$ \\
\hline$[\mathbf{1 3}]$ & 17000 & 28500 & $1 / 1.7$ \\
\hline$[\mathbf{1 4}]$ & 3000 & 32000 & $1 / 10$ \\
\hline$[\mathbf{1 5}]$ & 1000 & - & - \\
\hline
\end{tabular}

In a study carried to determine aerated concrete wall modulus of elasticity values [16], the modulus of elasticity of a wall constructed with A2 class aerated concrete and without plaster was reported as $1500 \mathrm{MPa}$. The modulus of elasticity of a plastered wall was reported as $2091 \mathrm{MPa}$, unit weight was reported as $400 \mathrm{~kg} / \mathrm{m}^{3}$ and compressive strength was reported as 2.5MPa. In [17], masonry aerated concrete blocks were cut into $10 \times 10 \times 10 \mathrm{~cm}^{3}$ cubes and $10 \times 10 \times 40 \mathrm{~cm}^{3}$ prisms and their modulus of elasticity values and Poisson ratios were experimentally determined. Resultant values are summarized in Table IV. In [18], modulus of elasticity of aerated concrete of a wall panel was identified as $1750 \mathrm{MPa}$. Specifications of Turkish Aerated Concrete Producers Association for aerated concrete of wall blocks are provided in Table V [2].

TABLE IV. PHYSICAL ATTRIBUTES OF AERATED CONCRETE WALL

\begin{tabular}{|c|c|c|c|c|}
\hline $\begin{array}{c}\text { Specific } \\
\text { gravity } \\
\left(\mathbf{N} / \mathbf{m}^{\mathbf{3}}\right)\end{array}$ & $\begin{array}{c}\text { Mean cube } \\
\text { strength } \\
(\mathbf{M P a})\end{array}$ & $\begin{array}{c}\text { Mean } \\
\text { prismatic } \\
\text { strength }(\mathbf{M P a})\end{array}$ & $\begin{array}{c}\text { Mean initial } \\
\text { modulus of } \\
\text { elasticity(MPa) }\end{array}$ & $\begin{array}{c}\text { Mean } \\
\text { Poisson } \\
\text { ratio }\end{array}$ \\
\hline $7500-8000$ & 4.90 & 3.32 & 1620 & 0.21 \\
\hline 9000 & 4.60 & 3.08 & 1570 & 0.20 \\
\hline $8000-8500$ & 3.60 & 2.64 & 1490 & 0.19 \\
\hline
\end{tabular}

TABLE V. AERATED CONCRETE WALL BLOCKS

\begin{tabular}{|c|c|c|c|c|c|}
\hline Material strength class & A2 & A3 & A4 & Unit \\
\hline Mean compressive strength & 2.5 & 3.5 & 5.0 & $\mathrm{MPa}$ \\
\hline Modulus of elasticity & 1250 & 1750 & 2250 & 2750 & $\mathrm{MPa}$ \\
\hline
\end{tabular}

\section{Equivalent Diagonal Strut Model}

Previous studies conducted to determine and elucidate the linear behaviors of infill walls [19, 20] revealed diagonal cracks at the center of the modeled panel, voids between the frame and infill at opposite unloaded corners of the model, and a full contact at the other two loaded diagonal corners. To reflect such behaviors on actual infill walls and to facilitate the analysis of infill wall frame systems, infill walls were placed as equivalent compression struts (Figure 1). The compressive load-bearing region was represented with an equivalent diagonal strut in static analysis of frame systems under external forces (Figure 2). 


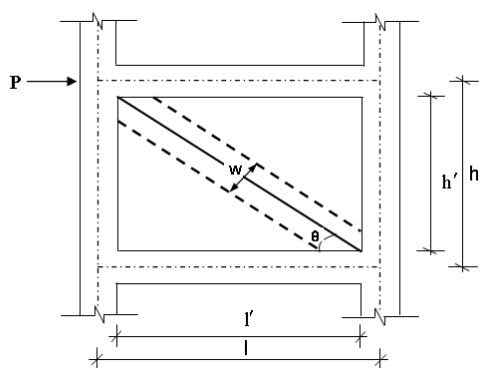

Fig. 1. Representation of infill wall analysis model

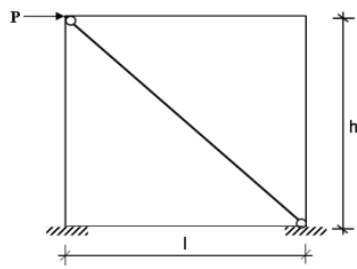

Fig. 2. Representation of infill wall frames with two end-hinged equivalent virtual diagonal bar

Different researchers used different assumptions in calculating the thickness of equivalent diagonal struts. Authors in $[19,20]$ proposed (1) and (2) for strut width representing the infill wall:

$$
\begin{aligned}
& w=0.175(\lambda h)-0.4 \sqrt{h^{\prime}+I^{\prime}} \\
& \lambda=\sqrt[4]{\frac{E_{m} t \sin 2 \theta}{4 E_{c} I_{c} h^{\prime}}}
\end{aligned}
$$

The compressive load-bearing region was represented with an equivalent virtual bar in static analysis of frame systems under external forces (Figure 2). The value of $\theta$ used in (2) is calculated with the aid of (3):

$$
\theta=\tan ^{-1}\left(h^{\prime} / I^{\prime}\right)
$$

where $w$ is the width of equivalent diagonal compression strut, $\lambda$ is the rigidity parameter of the infill and frame, $h$ the floor height, $l$ the frame span, $h^{\prime}$ the infill wall height, $l$ 'the infill wall width, $E_{m}$ is the modulus of elasticity of equivalent virtual compression strut, $t$ the infill wall thickness, $\theta$ the angle of equivalent virtual compression strut from the horizontal plane, $E_{c}$ the frame modulus of elasticity, and $I_{c}$ is the column moment of intertia.

\section{E. Partially Infilled Frames}

Infill walls are either constructed without openings or they may have window and door spaces. In such a case, equivalent compression strut width is multiplied with a reduction factor to include loss of strength due to these void spaces into calculations [21].

$$
\begin{aligned}
& W_{\text {reduction }}=W\left(R_{1}\right)_{i}\left(R_{2}\right)_{i} \\
& \left(R_{1}\right)_{i}=0.6 \times\left(\frac{A_{\text {gap }}}{A_{\text {panel }}}\right)^{2}-1.6 \times\left(\frac{A_{\text {gap }}}{A_{\text {panel }}}\right)+1
\end{aligned}
$$

where $A_{\text {gap }}$ is the total area of void spaces over the infill wall, $\mathrm{A}_{\text {panel }}$ is the full area of infill wall without voids, $\left(R_{l}\right)_{i}$ the expression of reduction factor for infill walls with void spaces, and $\left(R_{2}\right)_{r}$ the expression of reduction factor for existing infill damages.

In cases where infill walls have window and door spaces, the reduction factor $R_{l}$ is applied on the calculations made for the width of equivalent compression strut. In cases where there aren't any damages on infill walls, then $R_{2}$ is considered as 1 . In cases where there are heavy damages, $R_{2}$ can be taken as 0 since the wall will have slight contributions to building rigidity due to breakouts between the frame and the infill wall. In such cases, the wall will contribute only to the weight of the building and will not have any contributions to lateral rigidity.

\section{BUILDING MODEL}

A building was modeled with two different infill wall materials to investigate their effects on structural irregularities. Total floor height (HN) was $15 \mathrm{~m}$ and the elasticity level was high. Earthquake analysis of a regular structure was performed with equivalent seismic load method.

TABLE VI. BUILDING INFORMATION

\begin{tabular}{|c|c|}
\hline \multicolumn{2}{|c|}{ Building Information } \\
\hline Slab & $12 \mathrm{~cm}$ \\
\hline Interior wall thickness (brick and aerated concrete) & $10 \mathrm{~cm}$ \\
\hline Exterior wall thickness (brick and aerated concrete) & $20 \mathrm{~cm}$ \\
\hline Beam dimensions & $25 \times 50 \mathrm{~cm}$ \\
\hline Column dimensions & $40 \times 40 \mathrm{~cm}$ \\
\hline Concrete class & $\mathrm{C} 30$ \\
\hline Concrete modulus of elasticity (Ec) & $32000 \mathrm{MPa}$ \\
\hline Brick wall modulus of elasticity (Ew) & $1000 \mathrm{MPa}$ \\
\hline Aerated concrete wall modulus of elasticity (Ew) & $2091 \mathrm{MPa}$ \\
\hline Number of floors & 10 \\
\hline Bearing system type & $\mathrm{R} . \mathrm{C} . \mathrm{Frame}$ \\
\hline Floor height & $3 \mathrm{~m}$ \\
\hline Earthquake zone & 1 \\
\hline Local ground class & 0,4 \\
\hline Effective ground acceleration coefficient & $\mathrm{Z} 3$ \\
\hline Spectrum characteristic periods & $\mathrm{TA}=0.15 \mathrm{sn}$ \\
\hline
\end{tabular}

Building ax along $\mathrm{x}$ direction are $\mathrm{A}, \mathrm{B}, \mathrm{C}, \mathrm{D}, \mathrm{E}$ and $\mathrm{F}$ and axle spacing was $5 \mathrm{~m}$ (Figure 3 ). The axles along y direction are $1,2,3$ and 4 and ax spacing was $4 \mathrm{~m}, 2 \mathrm{~m}$ and $4 \mathrm{~m}$. Except for the window in the hall, the size of all windows was $150 \times 130 \mathrm{~cm}^{2}$ and the door size was $90 \times 220 \mathrm{~cm}^{2}$. The size of the window at the hall was $100 \times 200 \mathrm{~cm}^{2}$. The building was considered as separated from a-axle with a joint to separate shear wall effect from the building, in this way, the effects of infill wall on the building were analyzed.

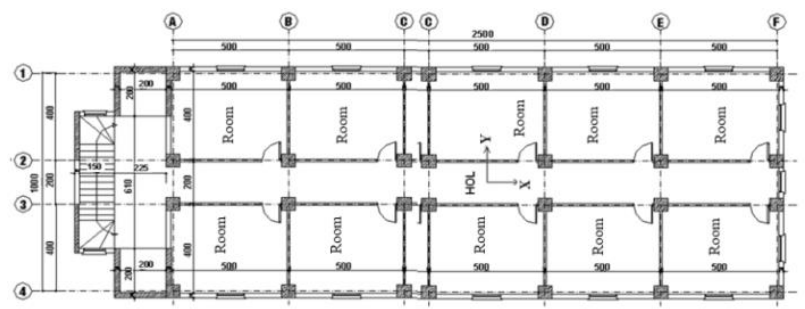

Fig. 3. Building model 
The abbreviations for the model are: BEF: empty frame modeled though taking brick wall only as weight, BWF: the frame with brick wall, AEF: empty frame modeled though taking aerated concrete wall only as weight, AWF: the frame with aerated concrete wall. Normal floor weight $(\mathrm{N})$, roof-floor weight $(\mathrm{R})$ and total building weight at an incidence of earthquake (W) are provided in Table VII.

TABLE VII. BUILDING FLOOR WEIGHTS

\begin{tabular}{|c|c|c|c|c|}
\hline \multirow{2}{*}{ Floor } & \multicolumn{4}{|c|}{$\boldsymbol{w}_{\boldsymbol{i}}(\boldsymbol{t})$} \\
\cline { 2 - 5 } & $\mathbf{B E F}$ & $\mathbf{B W F}$ & $\mathbf{A E F}$ & AWF \\
\hline $\mathbf{N}$ & 287.25 & 287.25 & 252.85 & 252.85 \\
\hline $\mathbf{R}$ & 228.19 & 228.19 & 217.22 & 217.22 \\
\hline $\mathbf{W}$ & 2813.44 & 2813.44 & 2492.87 & 2492.87 \\
\hline
\end{tabular}

Building total weight was reduced by $11.36 \%$ with the use of aerated concrete wall instead of brick wall. The first natural vibration period of 10 -story building along the y-axis was calculated with the aid of Rayleigh ratio. Period values are provided in Table VIII.

TABLE VIII. PERIOD VALUES OF THE BUILDING

\begin{tabular}{|c|c|c|c|}
\hline \multicolumn{4}{|c|}{ Period (s) } \\
\hline BEF & BWF & AEF & AWF \\
\hline 1.38 & 1.17 & 1.28 & 1.01 \\
\hline
\end{tabular}

Period values decreased by $7.25 \%$ with decrease in building weight. Weight and modulus of elasticity together decreased period values by $13.68 \%$. Period values decreased by $15.22 \%$ with the modeling of brick wall and $21.09 \%$ with the modeling of aerated concrete wall (Table IX). Total equivalent seismic load of 10-story building along the y-axis (base shear force) $\left(V_{t}\right)$ was calculated and provided in Table X. Base shear force values decreased by $6.91 \%$ with decrease in building weight. Weight and modulus of elasticity together reduced base shear force values by $7.35 \%$. Base shear force values increased by $13.70 \%$ with the modeling of brick wall and by 13.155 with the modeling of aerated concrete wall (Tables X-XI).

TABLE IX. \% EDUCTIONS IN BUILDING PERIOD VALUES

\begin{tabular}{|c|c|c|c|}
\hline BWF/BEF & AWF/AEF & AEF/BEF & AWF/BWF \\
\hline 15.22 & 21.09 & 7.25 & 13.68 \\
\hline
\end{tabular}

TABLE X. BASE SHEAR FORCE VALUES

\begin{tabular}{|c|c|c|c|}
\hline BEF & BWF & AEF & AWF \\
\hline 183.00 & 208.07 & 170.36 & 192.77 \\
\hline
\end{tabular}

TABLE XI. \% CHANGES IN BUILDING BASE SHEAR FORCE

\begin{tabular}{|c|c|c|c|}
\hline BWF/BEF & AWF/AEF & AEF/BEF & AWF/BWF \\
\hline$(+) 13.70$ & $(+) 13.15$ & 6.91 & 7.35 \\
\hline
\end{tabular}

Equivalent seismic loads were affected on the displaced center of gravity considering $+5 \%$ additional eccentricity at floor alignments $\left(e_{y}=0.5\right)$. Eccentricity-induced displacement values for the 10th floor of the building are provided in Table XII. Reductions in displacement values were also calculated and are provided in Table XIII.
TABLE XII. DISPLACEMENT VALUES OF 10TH FLOOR

\begin{tabular}{|c|c|c|}
\hline Frames & $\left(\boldsymbol{d}_{\boldsymbol{i}}\right)_{\min }(\mathbf{m})$ & $\left(\boldsymbol{d}_{i}\right)_{\max }(\mathbf{m})$ \\
\hline BEF & 0.0410 & 0.0579 \\
\hline BWF & 0.0343 & 0.0470 \\
\hline AEF & 0.0382 & 0.0539 \\
\hline AWF & 0.0235 & 0.0318 \\
\hline
\end{tabular}

TABLE XIII. \% REDUCTIONS IN BUILDING DISPLACEMENT VALUES

\begin{tabular}{|c|c|c|c|c|c|c|c|c|}
\hline \multirow{2}{*}{ Floor } & \multicolumn{2}{|c|}{ BWF/BEF } & \multicolumn{2}{c|}{ AWF/AEF } & \multicolumn{2}{c|}{ AEF/BEF } & \multicolumn{2}{c|}{ AWF/BWF } \\
\cline { 2 - 9 } & min. & max. & min. & max. & min. & max. & min. & max. \\
\hline $\mathbf{1 0}$ & 16.37 & 18.80 & 38.49 & 41.07 & 6.87 & 6.88 & 31.50 & 32.42 \\
\hline $\mathbf{9}$ & 16.75 & 19.06 & 39.03 & 41.46 & 6.87 & 6.88 & 31.79 & 32.65 \\
\hline $\mathbf{8}$ & 17.07 & 19.24 & 39.51 & 41.88 & 6.89 & 6.90 & 32.09 & 32.99 \\
\hline $\mathbf{7}$ & 17.32 & 19.35 & 39.95 & 41.96 & 6.86 & 6.89 & 32.36 & 32.99 \\
\hline $\mathbf{6}$ & 17.58 & 19.42 & 40.29 & 42.11 & 6.90 & 6.90 & 32.55 & 33.12 \\
\hline $\mathbf{5}$ & 17.72 & 19.37 & 40.60 & 42.16 & 6.88 & 6.91 & 32.78 & 33.21 \\
\hline $\mathbf{4}$ & 17.71 & 19.17 & 40.77 & 42.05 & 6.92 & 6.90 & 32.99 & 33.26 \\
\hline $\mathbf{3}$ & 17.50 & 18.67 & 40.63 & 41.65 & 6.96 & 6.87 & 33.04 & 33.19 \\
\hline $\mathbf{2}$ & 16.57 & 17.50 & 39.93 & 40.52 & 6.90 & 6.90 & 32.97 & 32.88 \\
\hline $\mathbf{1}$ & 13.73 & 14.23 & 36.94 & 37.03 & 6.72 & 6.82 & 31.82 & 31.59 \\
\hline
\end{tabular}

Maximum displacement graphs of the 10-story building for different column sizes were drawn for all floors. Displacements increased with increasing number of floors (Figure 4).

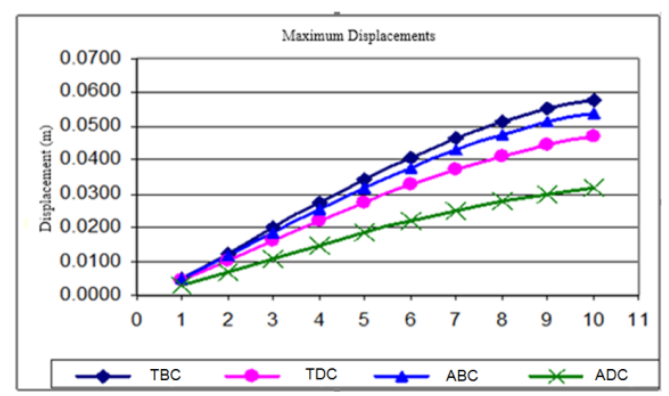

Fig. 4. Maximum deflection graphs of the building

Earthquake analysis for all frame systems of the building revealed that torsion irregularity, rigidity irregularity, relative floor displacement and second-order indicator values were below the limit values specified in [23].

\section{CONCLUSION AND DISCUSSION}

In previous experimental studies, brick wall modulus of elasticity values were reported between $1000 \mathrm{MPa}-4272 \mathrm{MPa}$ and the taken value of $1000 \mathrm{MPa}$, based on concrete class for hallow bricks used in construction of a hotel, was found to be suitable [14]. With the use of aerated concrete instead of brick in infill walls, the building's total weight decreased by $11.36 \%$, period values decreased by $7.25 \%$, base shear force values decreased by $6.91 \%$ and displacements decreased by $6.72 \%$ $6.96 \%$. Weight and modulus of elasticity together reduced period values by $13.68 \%$, shear force values by $7.35 \%$ and displacements by between $31.50 \%-33.26 \%$. With the model of brick wall, period values decreased by $15.22 \%$, shear force values increased by $13.70 \%$ and displacements decreased by between $13.73-19.42 \%$. With the modeling of aerated concrete, period values decreased by $21.09 \%$, shear force values increased by $13.15 \%$ and displacements decreased by between $36.94 \%-42.16 \%$. Eventually, in Turkey where frequent 
earthquakes and heavy destructions are experienced, no concessions should be made on the quality and rigidity of the buildings. Therefore, the behavior of any single constructional member should be well-known and calculations should be made accordingly. Previous studies and present analysis reveal that infill walls have great contributions to building behavior under lateral loadings like earthquakes and negligence will bring about various negative outcomes. It is recommended that these existing structural members should definitely be included into calculations to improve positive impacts of infill walls on structure strength, elasticity and rigidity.

\section{ACKNOWLEDGMENT}

This study was supported by the Scientific Research Projects Department of Cukurova University (Project No: MMF2008YL3).

\section{REFERENCES}

[1] P. Govindan, M. Lakshmipaty A. R. Santhakumar, "Ductility of Infilled Frames", Journal Proceedings, Vol. 83, No. 4, pp. 567-576, 1986

[2] E. Vintzeleou, "Infilling of Reinforced Concrete Frames as a Strengthening Intervention", Seminar on the Assesment and Redesign of Reinforced Concrete Structures, Izmir, Turkey, 1989

[3] P. Negro. G. Verzeletti, "Effect of Infills on the Global Behaviour of R/C Frames:Energy Considerations from Pseudo-dynamic Tests", Earthquake Engineering and Structural Dynamics, Vol. 25, No. 7, pp. 753-773, 1996

[4] I. H. Cagatay, "Binalarda Kisa Kolona Etki Eden Parametrelerin Incelenmesi", Altinci Ulusal Deprem Muhendisligi Konferansi (Sixth National Earthquake Engineering Conference), Istanbul, Turkey, October 16-20, 2007 (in Turkish)

[5] R. Zarnic, "Modelling of Response of Masonry Infilled Frame", 10th Europen Conference on Earthquake Engineering, Vienna, Austria, August 28-September 2, 1995

[6] A. Kocak, Depreme, Dayanikli Yapi Tasarimi Ders Notlari, Yildiz Teknik Universitesi, 1998 (in Turkish)

[7] H. Bilir Ozhan, I. H. Cagatay, "Mechanical Behavior of Brick Masonry Panels Under Uniaxial Compression", Journal of Mechanics of Materials and Structures, Vol. 9, No. 4, pp. 385-395, 2014

[8] I. O. Demirel, E. Canbay, B. Binici, A. Yakut, Z. Eryurtlu, "Gazbeton Dolgulu Betonarme Cercevelerin Deprem Performansi Uzerine Deneysel Çalisma”, 3. Turkiye Deprem Muhendisligi ve Sismoloji Konferansi (Turkey Earthquake Engineering and Seismology Conference), Izmir, Turkey, October 14-16, 2015 (in Turkish)

[9] I. Aydogdu, Dolgu Duvarli Cercevelerin Davranisi, MSc Thesis, Yildiz Teknik Universitesi, 1995 (in Turkish)

[10] E. Yalcin, Dolgu Duvarlari ve Konumlarinin Cok Katli Betonarme Yapilarin Deprem Kuvvetleri Altindaki Davranisina Etkileri, MSc Thesis, ITU, 1999 (in Turkish)

[11] I. H. Cagatay, S. ve Guzeldag, Yeni Deprem Yonetmeligi (TDY-98) SAP2000N Uygulamalari, Birsen 2002 (in Turkish)

[12] O. Oktem, Betonarme Cerceve Sistemlerinin Lineer Olmayan Hesabi ve Dolgu Duvarların Modellenmesi, MSc Thesis, ITU, 2003 (in Turkish)

[13] E. Dundar, Cok Katli Betonarme Yapılarda Bolme Duvarlarının Deprem Davranisina Etkisi, MSc Thesis, Cukurova Universitesi, 2007 (in Turkish)

[14] A. Budak, Dolgu Duvarli Cercevelerin Sonlu Elemanlar Yontemi Ile Malzeme Bakimindan Dogrusal Olmayan Hesabi, PhD Thesis, Karadeniz Teknik Universitesi, 1997 (in Turkish)

[15] S. Donmez, Deprem Etkisinde Betonarme Binalarda Hasarin Olusmasinda Dolgu Duvarların Modellenmesi ve Tasiyici Sisteme Katkisi, MSc Thesis, ITU, 2006 (in Turkish)
[16] B. Yucesan, Betonarme Cercevelerin Guclendirilmesinde Yuksek Dayanimli Tugla Duvarlar, MSc Thesis, ITU, 2005 (in Turkish)

[17] A. Karaduman, "Dolgu Duvarli Cercevelerin Yatay Yukler Altindaki Davranislari Uzerine Deneysel Bir Calısma", Muhendislik Fakultesi Muhendislik Bilimleri Dergisi, (Journal of Engineering Sciences), Pamukkale University, Vol. 11, No. 3, pp. 345-349, 2005 (in Turkish)

[18] Z. Babayev, C. Eyyubov, I. Murat, C. Askerov, "Kirec Tasiyla Yapilmis Tasiyici Duvarların Dusey ve Yatay Yuklerin Etkisi Altindaki Davranisinin Arastirilmasi", ACE Fifth International Congress on Advances in Civil Engineering, ITU, Istanbul, 2002 (in Turkish)

[19] H. Sesigur, O. C. Celik, F. Cili, "Deprem Riski Dusuk Bolgelerde Orta Yukseklikteki Donatili Gazbeton Binalarin Uygulanabilirligi, Altinci Ulusal Deprem Muhendisligi Konferansi (Sixth National Earthquake Engineering Conference), Istanbul, Turkey, October 16-20, 2007 (in Turkish)

[20] B. S. Smith, C. A. Carter, "Method of Anlaysis for Infilled Frames", Proceedings of the Institution of Civil Engineers, Vol. 44, No. 1, pp. 3148, 1969

[21] R. J. Mainstone, "On the Stiffness and Strengths of Infilled Frames", in: ICE Proceedings, Suppl. iv, pp. 57-90, 1974

[22] E. Caglayan, "Betonarme Cercevelerin Yatay Yuklere Gore Analizinde Dolgu Duvar Etkisinin Incelenmesi, MSc Thesis, Fen Bilimleri Enstituss - Manisa Celal Bayar Universitesi, 2006 (in Turkish)

[23] Turk Deprem Yonetmeligi, Deprem Bolgelerinde Yapilacak Yapilar Hakkinda Yonetmelik, 264542007 (in Turkish) 